\title{
TEAM COOPERATION AND ITS IMPLICATIONS ON IMPROVING QUALITY OF EDUCATION IN SCHOOL
}

\author{
Siti Rochanah \\ State University of Jakarta \\ sitirochanahunj@gmail.com
}

\begin{abstract}
This research aims to know and to obtain an overview of quality of education improvement through teamwork in SMKN 48 Jakarta. This research was conducted in June until September 2016. The approach used is a qualitative approach with descriptive method. Data collection was done through an interview, observation, and study documentation. Data are from principal's and supported teachers as informants. Based on the results of research and data analysis, it can be concluded that teamwork have a very dominant role in improving the quality of the school. Teamwork formed by the principal's consist of teachers, committee and parents. The team's success can be seen from the many achievements that have been attained by the students and the school. Coordination happens in teams always do good communication and mutual help to each other. As the main actors in the school in improving the quality of education, the principal's needs to improve its ability to instruct the task, the participation and control of the situation. The principal's orientation in involving the various parties in the activities that advance the quality of schools in developing a culture of discussion is the action that had been very precise. Through the teamwork the quality of education in these schools be increased.
\end{abstract}

Keywords: Quality School, Teamwork, Educational Improvement

Education is a vehicle to develop all the potential and talent in order to be beneficial for the personal as well as the interests of the people. Formal education process is done in school or madrasah. Schools have a very important role in providing further education after a person receives education in his or her family environment. Therefore, the school has the task of educating, teaching, improving and refining the behavior of students who brought from their families. If that hope can be realized by the school, then the school is considered qualified. Quality management of education is a very important activity in schools, because with the quality will greatly support the success of the learning process in school.

The demand for quality education is also realized by the principal and teachers of SMKN 48 East Jakarta which is a vocational high school that already has a accreditation and become a school RSBI. Since renamed from previously named SMEA 30 in 1979, a series of achievements have been etched by SMKN 48 East Jakarta in both academic and non academic fields. Achievement of the above 
achievements, of course not easy because all schools that follow the race has prepared their respective strategies to win. And success is a result of teamwork, not individual work, coordinated by the principal and his representatives. The results of synergistic team work that will then result in high achievement.

According to Procter and Gamble quoted by Evans and Lindsay (2011: 11) "total quality is the unyielding and continually improving effort by everyone in an organization to understand, meet and exceed the expectations of customers". According to Garvin and Davis quoted by Nasution (2005: 3) "quality is a dynamic condition related to products, people / labor, processes and tasks, and environments that meet or exceed the expectations of customers or consumers". Meanwhile According to Adediran Oluwatoyin and Adediran Oluseun (2008: 5) "quality is a significant element of production or services in keeping the customers satisfied".

In the context of education, the success of learners in achievement is one determinant of the quality of a school. According to Lynton Gray, quoted by Sallis (2010: 62) "Assessing the quality of education is very different from examining the production of a factory or assessing a service." The culture applied in the school becomes an influential in the quality of education applied by a school. Cultural change is characterized by an understanding that people produce quality. Sallis (2010) states that there are two important things that staff need to produce quality that is staff and work environment. The quality of service businesses such as education, has several dimensions. Quality dimensions according to Berry and Parasuraman cited by Nasution (2005: 5) have five dimensions of quality that can be used by customers in evaluating the quality of services, namely: direct evidence, reliability, responsiveness, assurance and empathy.

Nasution (2005) states that Team is a group of people who have a common goal. The formation of a team does not by itself work as expected. For that it is necessary to overcome the factors that inhibit the success of teamwork and also required various efforts for the team to achieve the mission and objectives of its formation. According to John cited by Sallis (2010), "teamwork within an organization is an important component of TQM implementation, given that teamwork will increase confidence, communications, and develop independence. Cooperation is the people who are said to work together when their efforts are systematically combined to achieve a common goal. Kreitner and Kinicky (2014: 4) state the greater the merger, the greater the degree of cooperation. A successful team is very concerned with the results achieved. They repeatedly request feedback on their achievements and follow up their findings with action.

According to Parks and Sanna quoted Levi (2007: 5) "most definitions of teamwork classify a team as a special type of group. To some theorists, the distinction between groups and teams is fuzzy; Teams are simply groups in work settings ". According to Evans and Lindsay (2011: 283) "a teamwork is a small number of people with complementary skills that are committed to a common purpose, set of performance goals, and an approach for which they hold themselves 
mutually accountable in works". According to Parker cited by Kreitner and Kinicki (2014: 23) there are 12 characteristics of effective teamwork: clear, informal, listening, participation, civil strife, consensus decision, open communication, clear role,. Based on the above description, the authors are interested in conducting research on "Improving the Quality of Education through Teamwork at SMKN 48 East Jakarta".

\section{METHOD}

The study used a qualitative approach. This approach requires researchers to go directly to the field to observe the processes that occur during the research activities take place. This activity aims to get the data in the form of description. Researchers get descriptive data through observation techniques, interviews, and documentation studies. In this study, the source of data is the Head of SMKN 48 East Jakarta as a key informant and teachers. The research was conducted at $S M K$ Negeri 48 East Jakarta, located at Raden Inten Street, East Jakarta. This research was conducted in June-September 2016. The type of data collected and used in this study is qualitative data. Taken by several informants using snowball or snowball technique. In this study, the informants included principals and teachers. Data are obtained from all concerned parties, either through interviews, observation, and documentation.

\section{RESULTS}

48 State Vocational School or SMK Negeri 48 is located on Jalan Raden Inten II no 3 East Jakarta with accreditation value A. SMK Negeri 48 is known today in the process has experienced several times the name of the school and the headmaster who led it. Year 1979 - 1981 with the name SMEA Negeri 2 class far from class away SMEA Negeri 2 Jakarta. In the Year 1981 - 1982 became SMEA Negeri 8 class far. Naming became SMK Negeri 48 passed through the Decree of the Minister of Education and Culture of the Republic of Indonesia Number: 036/0/1979 dated 7 March 1979 SMEA Negeri 30 Jakarta became SMK Negeri 48 Jakarta Business and Management Group. In the year of 2016/2017, SMK Negeri 48 Jakarta has 826 students divided into 5 study programs: (1) Accounting, (2) Office Administration, (3) Marketing, (4) Multimedia, and (5) Production Program Technique Broadcasting and television.

Since it was still named SMEA Negeri 30 Jakarta Until the period of 1989, gradually managed to make the school known by the community along with the achievements of both the curricular curriculum in that period can be said to grow quite rapidly, especially for Scout activities and sacred sites. While academic achievement is achieved among others: 1st Winner of Typing Competition DKI level.

In the period 1989-1992. Extra curricular activities SMEA Negeri 30 increases with Red Cross Youth, Theater and Paskibra. Achievements achieved in 
the period is more in earnings from extra-curricular activities, because at that time the creativity of students really channeled, although not meant for academic achievement decline. In line with the inauguration of the name of SMK Negeri 48 in 1979, extra curricular activities experienced a declining period of achievement, due to the curriculum that requires students to implement Dual System Education (PSG) in the business / industry (DUDI) for 1 (one) to 3 (three) Month so that extra-curricular activities get less attention. However, in academic field, achievement has increased, which is marked by more students who get good result in academic (curricular) than extra curricular, among others by becoming the first winner in skill competition of students of DKI Jakarta level for 2 (two) Secretary and Business Management, as the first winner of the Right Rapid Competition held at RRI Jakarta, the first winner of Accounting at Jakarta Level, winner of Taxation Competition and Cooperative of DKI Jakarta and several others, although not the first winner.

Since 2000 the results achieved by students representing schools in several championships or competitions are: English Speech Competition champions held by DON BOSCO High School, and the last one is the 1st winner on Quick TVRI or at the event ABC- A Thinking Event Fast on TVRI. This will all be realized because the entire school community, ranging from Principals, Teachers, Administrative Officers, Students, Parents and even the surrounding community shoulder to shoulder and work together harmoniously and harmoniously.

Then in 2009 SMK Negeri 48 Jakarta is shown to be a pioneer school RSBI. This is partly due to Academic Achievements and Extra Curricular is very much achieved up to LKS National level. But in line with the closing of the RSBI program, starting in January 2012 the RSBI label on SMK Negeri 48 Jakarta again became the other schools. However, SMK Negeri 48 ranks 1st in East Jakarta Se DKI Jakarta for the State and private and the rank I SE DKI special public schools. Then in 2015, SMK Negeri 48 Jakarta won the National Integrated Science Olympiad in the subject of non-technical Mathematics DKI Jakarta. Since 2016, SMK Negeri 48 set as one of the schools that the process of computer-based national exam (CBT). Achievements achieved at the UN in 2016 is the second ranking of all SMK in Jakarta.

In school management, the head of SMK Negeri 48 has built a disciplined family atmosphere, a neat, pretative and productive environment in this school. This can facilitate the success of schools to improve the quality of education. SMKN 48 East Jakarta is a school that has accreditation A in the academic field. It can not be separated from the team formed by the principal, the team in the academic field consisting of the principal in charge, the teacher as the field coordinator and the members come from the teachers of the study areas that are contested. While the non-academic team formed by the principal and parents of the students is a School Committee team consisting of parents of students. 
The function of the team is in addition to improving the quality of education in this school is to increase the solidarity between school residents and parents so that all students can synergize to be able to provide the best for learners, this teamwork also serves as a means to implement school programs so that the purpose of school Can be realized. For teams in the field of non-academic exclusion team. However, this team is only conditional in accordance with the activities that will come.

The formation of a competition team in the academic field is conducted at the beginning of a new academic year or two months before the event takes place. As for non-academic teams conducted in the new school year. Both teams always coordinate with the leadership and members of the group if solving a problem that occurred. The process of forming a team in an activity that requires the participation of the committee and parents, the first principal to provide info that will be held an activity in school. Then the principal, teacher and meeting committee on the activity. The committee then disseminates the results of the meeting with the school to the class coordinator. After the consensus, the committee returned to provide information related to the meeting with korlas. After that, a large meeting was held between principals, teachers, committees, and parents related to the implementation of activities. Only then can the activity be carried out.

In operating the teamwork, it is important to see what team work is in it. This can be seen from team leadership, team coordination, team commitment, and team rewards. Coordination in the team is seen from teachers who always report every thing that happens when the activities of the principal. Current communication adds to the closeness of the coordination. Teachers help each other in the implementation of activities and even members who are not included in the committee, on the day of $\mathrm{H}$ or at the time of the activity took place, all down to the field to help. This is based on their strong commitment to realize the quality of superior education.

In preparing the students to join the race, the team work together in formulating the joint exercise questions to be tested to the participants. The preparation lasts for 1-3 months before the race begins. However, after the students enter the National and International competition then the coaching done by the school team is not done because it will be taken over by the government to be quarantined.

Principals always monitor the performance of these teams. The principal usually controls the team at the start of planning, implementation of activities, the end of activities aimed at improving the performance of the team in the future. The principal always fully supports all positive activities for learners to improve the quality of education. Principals always support morally and materially to activities related to learners and can improve the quality of education in this school. At the 
time of evaluating the principal always evaluate at the end of the activity so that the next activity will be arranged more neatly.

Teamwork at SMK Negeri 48 Jakarta is a teamwork established to improve the quality of education in schools. The team has the same vision and mission to advance education in this school. The communication that occurs within the team is very smooth and clear, so the risk of error is very small. They always coordinate and deliberate if there is a problem.

For that the school to try as best as possible in the planning and implementation of school programs by involving all components of the school community to facilitate learners. That is always open in the delivery of information in every school activities starting from the planning, such as the formation of the committee, the implementation of activities, at the end of the activity, until the next activity to be held. In addition, good communication in both directions is also a matter of concern in this teamwork. The success of a team is in the team's operations. A team's success measure is also seen at the time of operation of the team.

If in the operational team the team can run smoothly, the success of the team will be felt. In addition, the success of the team also has a direct and indirect impact. The indirect impact is in addition to accelerate the achievement of goals because it is done together, the closer is also the fabric of familial relationships between each other. The operation of the team can not be separated from the principal's leadership. Because the principal monitors the entire performance of the team until the achievement of an improved quality of education. With teamwork can also ease the burden of tasks and shortcomings can be minimized because with the team gave a lot of input ideas in the achievement of education quality in school.

\section{DISCUSSION}

Teamwork that took place in SMK Negeri 48 Jakarta is a combination of several people who work together to improve the quality of education in schools. This is supported by the theory put forward by Kreitner and Kinicki that cooperation is the people who are said to work together when their efforts are systematically combined to achieve common goals. The greater the merger, the greater the degree of cooperation. Based on the above research findings, SMK Negeri 48 Jakarta has a teamwork procedure that is in line with the theory put forward by Mulyasa which states that are: Determine common goals with clear, clarify expertise and responsibilities of members, provide time to determine how to work together, always Work together, put the idea into reality. Trust, team evaluation regularly and sustainably.

Characteristics of teamwork at SMK Negeri 48 ast Jakarta is to have clear objectives, to listen to each other, to participate, open communication, clear role, joint leadership, style diversity, self-assessment. This is similar to the theory put forward by Kreitner and Kinicki ie the vision, mission, goals, or task of the team 
has been defined and accepted by everyone in the team then the team has set clear goals. The atmosphere or climate in the team tends to be informal, comfortable, relaxed, and there is no tension or boredom. In participation there is much discussion and everyone is encouraged to participate in issuing ideas or ideas that can advance the team. In open communication, team members feel free to express their feelings about the task and performance of the team. In a team there is a clear expectation of the roles played by each team member. The division of tasks in the team is done fairly and must be in accordance with its ability. A team has a diversity of styles a person has. At any given time, the team checks how well the team is running and concludes effective performance.

\section{CONCLUSION}

Teamwork established by the headmaster of SMK Negeri 48 Jakarta consisted of teachers, committees and parents. With the structure, the principal becomes responsible for each activity, the teacher as the coordinator and implementer, the committee and the parents as facilitators and supporters. The entire formation of the committee is arranged by the principal then discussed by the citizens of the school and parents. The success of the team is evident from the many accomplishments achieved by learners and schools. Selection of team members based on experience held in the previous year.

Coordination that occurs within the team is always doing good communication and helping each other. If there is a problem not allowed to drag on and will soon be discussed by the team. Constraints in case of miss communication, confirming back the information sounded and rectified in accordance with the fact that the occurrence of miss communication can be minimized. The principal always supervises the performance of the team and the participants so that the activities to be followed run in accordance with the planning of the team. The principal evaluates the team's performance at the end of the activity so that the next activity goes according to plan and does not repeat the previous mistake. Implementation of teamwork at SMK Negeri 48 Jakarta has a positive impact on improving the quality of education. The impact is some of the achievements gained by learners. The achievement is successfully achieved the National Examination (UN) high level of DKI Jakarta, winning many academic and non academic competitions.

\section{REFERENCES}

Bader, Gloria E., Bloom, Audrey E., \& Chang, Richard Y. (1998). Mengukur Prestasi Tim. (M. Indriadi, Trans.) Jakarta: Pustaka Binaman Pressindo.

Evans, James R., \& Lindsay, William M. (2011). The Management And Control of Quality. South Western: Cengage Learning.

Kreitner, Robert.,\& Kinicki, Angelo. (2014). Perilaku Organisasi. (B. B. Alkemis, Trans.) Jakarta: Salemba Empat.

Levi, Daniel. (2007). Group Dynamics For Teams. London: Sage Publications Ltd. 
Nasution, M. Nur. (2005). Manajemen Mutu Terpadu. Jakarta: Ghalia Indonesia.

National Assessment and Accreditation Council. (2003). Total Quality Management for Tertiary Education. Bangalore: National Assessment and Accreditation Council.

Oluwatoyin, Adediran., \& Oluseun, Adediran. (2008). Total Quality Management. Bleking: School Of Management, Bleking Institute of Technology.

Sallis, Edward. (2010). Manajemen Mutu Terpadu Pendidikan. (A. A. Riyadi, Trans.) Yogyakarta: IRCiSod. 